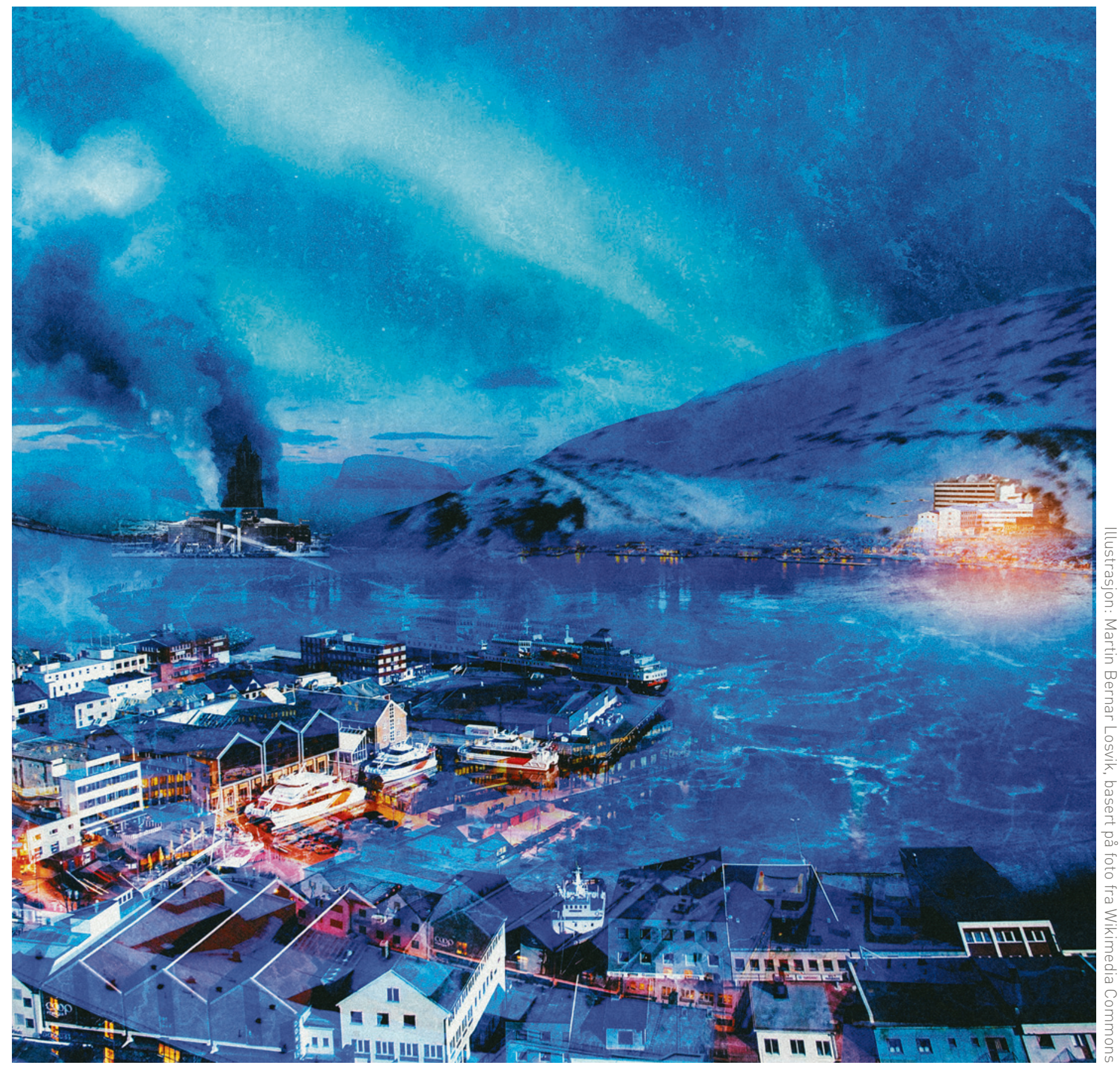

\title{
Klinikk Hammerfest
}

(i)

Klinikk Hammerfest er en del av Finnmarkssykehuset og har 95 sengeplasser fordelt på fagområdene kirurgi/ortopedi, indremedisin, gynekologi/fødsel og pediatri. Hammerfest by ligger på 70,7 ${ }^{\circ}$ nord og er lokalisert på Kvaløya med broforbindelse til fastlandet. 